\title{
Metaphors of Social Studies Teacher Candidates on Democracy
}

\author{
Ayşegül Tural \\ Department of Social Studies Education, Faculty of Education, Bartın University, Turkey
}

Copyright(C2018 by authors, all rights reserved. Authors agree that this article remains permanently open access under the terms of the Creative Commons Attribution License 4.0 International License

\begin{abstract}
Democracy is a form of government in which principle of equality is based, human rights and freedoms are protected. In this research, it is aimed to reveal democracy perceptions of social science teacher candidates through metaphors. Towards this aim, 105 social science teacher candidates are consulted about their democracy opinions. Study is a descriptive research, data is collected by phenomenology pattern which is one of the qualitative research methods in document examination way and collected data is resolved by content analysis. As a result of study, the results that are obtained from teacher candidates have developed valid 28 metaphors. It is seen that teacher candidates use mostly "freedom, scales and water" simulations while expressing democracy concept by metaphors which they develop.
\end{abstract}

Keywords Democracy, Metaphor, Social Studies, Teacher Candidates

\section{Introduction}

The democracy which represents form of government based on sovereignty of people [1] is defined as a social order in which individuals continue their lives by respecting rights and freedoms of individuals [2]. Habermas expresses democracy as a management mentality which protects human rights and freedoms; equality exists for all, emphasizes civil and private autonomy and is fed from common sources [3]. In view of Spinoza, democracy attracts attention as the best regime that is based on philosophy, science, human happiness and supports moral-intellectual development in individual and societal terms, as well as the principles which it has [4]. In this respect democracy and social information are two related concepts. It is expressed as a valuable process for individuals to internalize democracy for social culture, and be a conscious citizen with democratic retention, as $\mathrm{J}$. Dewey said, in making democracy a lifestyle [5]. Based on goal of educating good and effective citizens which is one of the fundamental aims of the social studies course; having democratic attitudes and to developing democracy consciousness is from the issues which keep actuality and importance in present day. Individuals' meeting with democracy is a process which is anticipated to start in the family and is developed in the school. In this process, schools have an important role in gaining democracy consciousness and in the stage of individual and social development [6]. Democracy education which starts in the family and continues in the school and social environment supports the process to form democratic-human rights based societies which focus on civic participation and influence individual and social development within scope of social responsibility [7]. In this respect, it is clear that it is necessary to attract attention to democracy education in all levels of education so that individuals and societies can internalize democracy, have democratic stance, possess knowledge, skills and awareness [8]. The citizenship, human rights and democracy education process is seen as important and necessary because it is intended to correct misknown theoretical and practical activities in education environments and clarify the topic of educating active citizens who respect to human rights, have democratic stance [9]. It is quite important to understand and comprehend human rights, citizenship and democracy in a way that is free from prejudices in scope of social studies course. Attention is attracted to the development process and effects of democracy in the process of education for the development of democratic attitudes at national and international levels of society [7]. It is seen necessary to approach democracy through a multidimensional association from education to economic structures at every stage of the state within the process of social development [10]. Democracy education is a universal process. Democracy which addresses all humankind aims to help people to feel that they are part of the society they live in and discover sense of belonging within the social structure [11]. It is seen as necessary to determine how individuals perceive democracy and issues that they know 
as incomplete or inaccurate by democracy education, at every stage in educational environments and focus on these issues [12]. It is clear that it is necessary to focus on the concept of democracy in study in terms of seen needs in the concepts of democracy, human rights and citizenship in individual and societal terms. In this study, metaphorical perceptions of social science teacher candidates regarding concept of "democracy" have been discussed. The metaphor which means defining a word by using simulations (figurative expressions) as word sense [1] is to associate at least two different concepts each other by figurative expressions and simulations [13]. The purpose of study is to examine developed metaphors by social studies teacher candidates regarding "democracy". It is thought that examination of developed metaphors by teacher candidates in relation to concept of "democracy" is important in terms of seeing what kinds of simulations about democracy are done, how concept of democracy which is kept in the social studies course is perceived and correlated with what kinds of simulations.

\section{Method}

This study, which democracy metaphors of social science teacher candidates are searched, is a descriptive study. The study is prepared in phenomenology pattern which is one of the qualitative research methods and data is analyzed by content analysis. Used phenomenology pattern in study focuses on phenomena that are not well understood in depth and detail. In the study process; it is seen appropriate to use phenomenology pattern to explain events which cannot be comprehended in depth [14].

\subsection{Study Group}

110 teacher candidates who are studying in the Social Studies Teacher Degree Program of a state university located in the Western Black Sea Region constitute study group. The volunteerism of teacher candidates is based in the participation process. The distribution of participants by gender and class level is shown in Table 1 .

Table 1. Variable Tables on Distribution of Participants

\begin{tabular}{|c|c|c|}
\hline Gender & Frequency & $\mathbf{\%}$ \\
\hline Female & 56 & 51.0 \\
\hline Male & 54 & 49.0 \\
\hline Class Level & & \\
\hline First grade & 32 & 29.1 \\
\hline Second grade & 31 & 28.2 \\
\hline Third grade & 30 & 27.3 \\
\hline Fourth grade & 17 & 15.4 \\
\hline TOTAL & 110 & 100.0 \\
\hline
\end{tabular}

When Table 1 is examined; it is seen that 56 participants
$(51 \%)$ are female, $54(49 \%)$ are male. 32 participants $(29.1 \%)$ are first grade, $31(28.2 \%)$ are second grade, 30 $(27.3 \%)$ are third grade and $17(15.4 \%)$ are fourth grade.

\subsection{Data Collection and Analysis}

Data is collected by document analysis in study and personal information form in which participants could express their gender and class levels and metaphors form is used to determine metaphorical perceptions of participants regarding concept of democracy as data collection tool. Since it is not known that participants did not participate in a metaphoric research before study process or not, metaphor examples for 2 concepts are shared in every class. Thus, it is wished to help participants to understand the rationale in the metaphor study. For that reason, it is asked social studies teacher candidates to finish "Democracy is like................... because .................." sentence in 30 minutes by aim of determining their metaphorical perception on "democracy" concept. The developed metaphors by prospective teachers regarding concept of "democracy" are taken as written and examined. Then, a classification is made about that teacher candidates have shaped/associated their metaphors of democracy with what kinds of simulations with the. A variety of categories have been set up based on conducted simulations about each classification and data is resolved. Metaphors of teacher candidates regarding concept of democracy are resolved by content analysis gradually:

\subsubsection{Data Coding and Extraction Stage}

At this stage, descriptive analysis of developed metaphors by participants is first done and obtained data is tabulated. The frequency-percentage values of developed metaphors by participants are given in table. Worksheets are numbered by ranking based on class-gender-sequence numbers of participants (eg 2M11, 4F100). Developed metaphors by teacher candidates in relation to concept of "democracy" are examined. Then working papers that contain metaphors 5 teacher candidates and are identified as irrelevant are removed from the analysis process. Metaphors which aren't included in study are given in Table 2.

Table 2. Weak Metaphors

\begin{tabular}{|c|c|c|c|}
\hline Rank & Code & Metaphor & $\begin{array}{c}\text { Extraction } \\
\text { Stage }\end{array}$ \\
\hline 1 & $2 \mathrm{M} 12$ & Snowman & Irrelevant \\
\hline 2 & $2 \mathrm{~F} 119$ & Cicada & Irrelevant \\
\hline 3 & $1 \mathrm{M} 30$ & Game & Irrelevant \\
\hline 4 & $1 \mathrm{~F} 31$ & Game & Irrelevant \\
\hline 5 & $1 \mathrm{M} 32$ & Game & Irrelevant \\
\hline
\end{tabular}

After extraction of irrelevant metaphors, it is continued to study with metaphors analysis which 105 people have developed. 


\subsubsection{Forming Categories}

At this stage, 3 categories have been formed by considering the relationship of data which is developed by participants on concept of democracy and planned to be included in the study in terms of metaphor-subject / content conformity. Formed categories are gathered under headings of "vital-social aspect, scientific-educational aspect and management aspect".

\subsubsection{Validity and Reliability Process}

In this study in which 28 valid metaphors are developed on concept of democracy, support has been taken from 2 field experts to ensure that study process is valid and reliable. The obtained data is presented to expert opinion and accordance between expert opinions is examined. The reliability and accordance to expert opinions of study is calculated by determining "agreement" and "disagreement" values in comparisons and by benefiting from formula of Miles \& Huberman [15] (Reliability = agreement / agreement + disagreement), accordance coefficient is obtained as 0.90 .

\section{Findings}

In this part of study, findings and analyzes related to developed metaphors by social science teacher candidates for the concept of democracy are included.

\section{Findings on metaphors regarding concept of democracy}

Findings on developed metaphors by social science teacher candidates regarding democracy concept are given in Table 3.

Table 3. Metaphors of teacher candidates

\begin{tabular}{|c|c|c|c|c|c|c|c|c|}
\hline \multirow{2}{*}{ Rank } & \multirow{2}{*}{ Metaphor } & \multicolumn{2}{|c|}{ f } & \multicolumn{4}{|c|}{ Grade } & \multirow{2}{*}{$\mathbf{f}$} \\
\hline & & Female & Male & 1. & 2. & 3. & 4. & \\
\hline 1 & Freedom & 10 & 9 & 6 & 6 & 4 & 3 & $19 * *$ \\
\hline 2 & Scales & 7 & 5 & 1 & 2 & 4 & 5 & $12 * *$ \\
\hline 3 & Water & 4 & 4 & 2 & 3 & 2 & 1 & $8 * *$ \\
\hline 4 & Sovereignty & 2 & 4 & & 3 & 3 & & 6 \\
\hline 5 & Life & 2 & 4 & & 3 & 2 & 1 & 6 \\
\hline 6 & Equality & 3 & 2 & 2 & 2 & 1 & & 5 \\
\hline 7 & Justice & 4 & 1 & 2 & 2 & 1 & & 5 \\
\hline 8 & Free thought & 2 & 3 & & 2 & 1 & 2 & 5 \\
\hline 9 & Human body & & 4 & 2 & & 1 & 1 & 4 \\
\hline 10 & Home & 3 & 1 & 1 & 1 & 2 & & 4 \\
\hline 11 & Love & 1 & 2 & 2 & & 1 & & 3 \\
\hline 12 & Sun & 2 & 1 & 3 & & & & 3 \\
\hline 13 & Solidarity & 1 & 1 & 1 & & 1 & & 2 \\
\hline 14 & Lifeblood & 1 & 1 & & 1 & 1 & & 2 \\
\hline 15 & Flower & 1 & 1 & & 1 & & 1 & 2 \\
\hline 16 & Tree & 2 & & & & 2 & & 2 \\
\hline 17 & Sky & 2 & & 2 & & & & 2 \\
\hline 18 & Breath & 1 & 1 & & 1 & & 1 & 2 \\
\hline 19 & Soil & & 2 & & & 2 & & 2 \\
\hline 20 & Money & 1 & 1 & 1 & & 1 & & 2 \\
\hline 21 & Family & 1 & 1 & & & 1 & 1 & 2 \\
\hline 22 & Gift & & 1 & & 1 & & & 1 \\
\hline 23 & Utopia & & 1 & & 1 & & & 1 \\
\hline 24 & Dream & 1 & & & & & 1 & 1 \\
\hline 25 & Child & 1 & & 1 & & & & 1 \\
\hline 26 & Medicine & 1 & & 1 & & & & 1 \\
\hline 27 & Oxygen & & 1 & 1 & & & & 1 \\
\hline 28 & Sky & 1 & & 1 & & & & 1 \\
\hline \multicolumn{2}{|c|}{ Total } & 54 & 51 & 29 & 29 & 30 & 17 & 105 \\
\hline
\end{tabular}


When Table 3 is examined, it is seen that social science teacher candidates have developed 28 valid metaphors about the concept of democracy. It is seen that in developed metaphors by teacher candidates mostly freedom (19), scale (12), water (8) simulations are repeated, at least gifts, utopias, dreams, children, medicine, oxygen and the sky (1) are repeated. When look at the table, it is understood that the freedom metaphor was repeated 19 times.

When look at table, it is understood that freedom metaphor is repeated 19 times. According to $1 \mathrm{~F} 23$ who is one of the teacher candidates who resemble democracy to freedom:

"Democracy is like freedom because human cannot freely make choices without democracy. "It is emphasized that democracy is intertwined with freedom and it allows people to live their freedom in example which democracy is like freedom simulation has been done. According to 4F101 who is one of the teacher candidates who resemble democracy to scales:

"Democracy is like scales because justice, fair governance, rights and freedoms must be balanced in democracy like the two sides of scales." When look at example, it is stated that democracy should balance and distribute justice, rights and freedoms like scales. It is seen that the water metaphor is repeated 8 times. According to $1 \mathrm{M} 18$ who is one of the teacher candidates who resemble democracy to water:

"Democracy is like water because how water is a must for human life, democracy is a national formation that is necessary for the societies.". It is pointed out that democracy is so important and valuable for humanity like water in example which democracy is resembled to water. According to 4F99 who says democracy is like dream which is from least repeated metaphors (1 time) by participant social studies teacher candidates:

"Democracy is like a dream because it exists if it is applied correctly, it will be an abstract dream like dream if not applied correctly". When example is examined, it is understood that teacher candidate who resembles democracy to dream touches on implementing democracy in a correct and effective way. According to $1 F 16$ who is one of the teacher candidates who say democracy resembles to child: scales:

"Democracy is like a child because democracy grows slowly and matures just like children." It is understood that teacher candidate expresses in the relevant example that democracy grows and develops slowly over time as a child and finds the right form. According to $1 \mathrm{~F} 5$ who is one of the teacher candidates who resemble democracy to medicine:

"Democracy is like medicine because people feel more secure and stronger where democracy is." When we look at simulation of democracy is like medicine, it is understood that democracy gives people and societies power and confidence like medicine. According to teacher candidate $1 \mathrm{~F} 13$ who resemble democracy to rainbow:

"Democracy is like a rainbow because all the colors are in it, and we gain our rights and freedom thanks to that." When look at example, it is expressed that democracy is a colorful concept like a rainbow and it contains rights and freedoms of people in it.

\section{Findings on Categorization of Metaphors Regarding Democracy Concept}

Table 4 shows categories related to developed metaphors by the social science teacher candidates for the concept of democracy.

It is seen that developed metaphors on democracy concept by social studies teacher candidates are categorized under headings of "vital-social aspects, science- education aspect and management aspect". When look at simulations of teacher candidates on democracy, it is seen that they group in category of "Vital-social aspects (49)", "Management aspect (49)", "Science- education aspect (7)".

Table 4. Categories according to metaphors of teacher candidates

\begin{tabular}{|c|c|c|c|}
\hline Category & $\begin{array}{c}\text { Metaphor } \\
\text { Number }\end{array}$ & Metaphors & f \\
\hline Vital-social aspects & 19 & $\begin{array}{c}\text { Water (8), Life (6), Human body (4), Sun (3), Life vessel (2), Home (4), Love } \\
\text { (3), Solidarity (2), Flower (2), Tree (2), Rainbow (1), Breath (2), Soil (2), } \\
\text { Family (2), Gift (1), Child (1), Medicine (1), Oxygen (1), Sky (2) }\end{array}$ & $\begin{array}{c}49 \\
\text { Management aspect }\end{array}$ \\
\hline $\begin{array}{c}\text { Science- education } \\
\text { aspect }\end{array}$ & 6 & Freedom (19), Libra (12), Sovereignty (6), Equality (5), Justice (5), Money (2) & 49 \\
\hline TOTAL & 3 & Free thinking (5), Utopia (1), Dream (1) & 7 \\
\hline
\end{tabular}




\section{Results}

In this research, it is aimed to examine perceptions of social science teacher candidates on democracy through metaphors. According to results of obtained findings in research process, it is seen that social science teacher candidates have developed 28 valid metaphors related to democracy. When look at developed metaphors, it is understood that mostly freedom (19), scale (12), water (8) simulations are repeated; at least gift, utopia, dream, child, medicine, oxygen and sky (1) simulations are repeated. At the results of that developed metaphors (simulations) by candidate candidates regarding concept of democracy accumulate under certain themes; "vital-social aspect (49)", "management aspect (49)", "science-education aspect (7)", results have been obtained. While metaphors regarding democracy are being produced in research done by Yağan Güder \& Yıldırım [6], it is seen that teacher candidates have emphasized on administrative dimension of democracy concept and concentrated on scale simulation. In this direction, results of the research support the study. The results of research in which associates concept of democracy with concepts of freedom and equality are compatible with this study [8]; [16]. Another research in which democracy perceptions of participants are examined by metaphors and notion of democracy exists intensively as freedom, power and management understanding also coincides with the results of this study [17]. The study which examines metaphors regarding independence value under being free and independence themes is also consistent with results of the study [18]. In another research, democracy perceptions of primary school students are researched and significant differences are found regarding the concepts of equality, human rights, independence. The research supports the related study in terms of these results [12]. As a result, at the end of process which attempts to reveal perceptions of participants on democracy through metaphors, it seems that teacher candidates have developed a number of validated metaphors related to the topic. The developed metaphors are important in terms of bringing in considerable issues at the point of human rights and freedoms.

Based on these results, the following suggestions can be made:

1. This research is a descriptive study that examines teacher candidates' perceptions on democracy by help of metaphors. In the following years, subject matter and scope can be extended by researchers and implementation can be repeated.

2. All education programs can include the development of democracy and democratic attitudes. Thus, it would be possible to support the acquisition of democratic consciousness through the theoretical and practical processes.

3. Concepts of democracy and topics that can be pointed to education of democracy can be discussed in educational environments such as congress, symposium, and it can be discussed in depth on subject.

\section{REFERENCES}

[1] Turkish Language Association (2017). Güncel Türkçe Sözlük. http://tdk.gov.tr cited 03.02.2018.

[2] Starkey, H. Democratic Citizenship, Languages, Diversity and Human Rights, Language Policy Division Directorate of School, Out-of-School and Higher Education DGIV Council of Europe, Strasbourg, 2002.

[3] Habermas, J. Constitutional Democracy A Paradoxical Union of Contradictory Principles? Political Theory, 29 (6), 766-781, 2001

[4] Ward, L. Modern Democracy and the Theological-Political Problem in Spinoza, Rousseau and Jefferson. New York: Palgrave Macmillan, 2014.

[5] Lee, J. K. Toward democracy: Social Studies and TPCK. (Ed. AACTE Committee on Innovation and Technology). Handbook of Technological Pedagogical Content Knowledge (TPCK) for Educators. First Edition. New York and London: Routledge Taylor \& Francis Group, 2008.

[6] Yağan Güder, S. Yıldırım, A. Preschool Teacher Candidates' Metaphors toward Democracy. Adiyaman Üniversitesi Sosyal Bilimler Enstitüsü Dergisi, 7 (16), 151-170, 2014.

[7] Howe, R, B. Covell, K. Empowering Children Children's Rights Education as a Pathway to Citizenship. Toronto Buffalo London: University of Yoronto Press, 2005.

[8] Sarı, M. Sadık, F. Öğretmen Adaylarının Demokrasi Algılarının Metaforlar Aracılığıyla İncelenmesi. Uluslararası Eğitim Programları ve Öğretim Çalışmaları Dergisi, 1 (2), 67-82, 2011.

[9] Akbaşlı, S. Sosyal Bilgiler Öğretiminde Vatandaşlık ve İnsan Hakları Eğitimi, Sosyal Bilgiler Öğretiminde Yeni Yaklaşımlar-1, (Ed. Turan, R., Sünbül, A. M., Hakan, H.), Ankara: Pegem A Yayıncılık, 2009.

[10] Barro,, J. R. Democracy and Growth. Journal of Economic Growth, 1 (March), 1-27, 1996.

[11] Andreopoulos, G. Human Rights Education And Training For Professionals, International Review of Education Internationale Zeitschrift für Erziehungswissenschaft Revue Internationale de l'Education, 48, 239-249, 2002.

[12] Kuş, Z. Çetin, T. Perceptions of Democracy of Primary School Students. Educational Sciences: Theory \& Practice, 14 (2), 1-22, 2014.

[13] Bulut, R. Koca, M. K. Sosyal Bilgiler Öğretmen Adaylarının Barış Kavramına İlişkin Metaforları. Turkish Studies, 12 (18), 139-156, 2017.

[14] Yıldırım, A. Şimşek, H. Sosyal Bilimlerde Nitel Araştırma Yöntemleri. Ankara: Seçkin Yayınevi, 2008.

[15] Miles, M. B. Huberman, A. M. Qualitative Data Analysis (Second Edition). London and New Delhi: Thousand Oaks, CA: Sage Publications, 1994. 
[16] Sadık, F. Sarı, M. Çocuk ve Demokrasi: İlköğretim Öğrencilerinin Demokrasi Algıları: Çukurova Üniversitesi Örneği. Cumhuriyet International Journal of Education, 1 (1), 48-62, 2012.

[17] Güzel Yüce, S. Demir, Ö. An Investigation of the Perceptions of Prospective Police Officers about
"Democracy" Concept through Metaphors. Turkish Journal of Police Studies, 13 (2), 147-178, 2011.

[18] Ulu Kalın, Ö. Koçoğlu, E. Sosyal Bilgiler Öğretmen Adaylarının Bağımsızlık Değerine Karșı Metaforik Algıları. Ahi Evran Üniversitesi Kırşehir Eğitim Fakültesi Dergisi (KEFAD), 18 (2), 419-434, 2017. 